\title{
Root Cause Analysis, Failures and Effects in pediatric total quality management: a scoping review
}

\author{
Análise de Causa Raiz, Falhas e Efeitos na gestão da qualidade total pediátrica: scoping review \\ Análisis de Causa Raiz, Fallas y Efectos en la gestión total de la calidad pediátrica: revisión del alcance
}

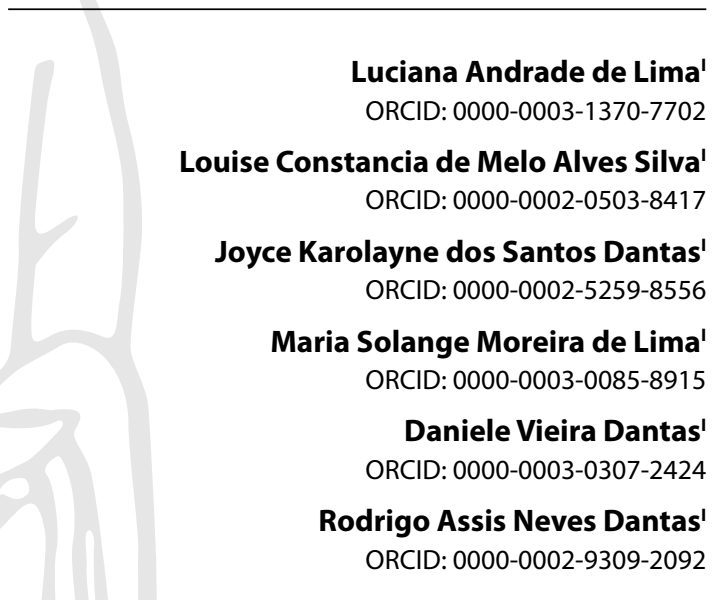

'Universidade Federal do Rio Grande do Norte. Natal, Rio Grande do Norte, Brazil.

How to cite this article: Lima LA, Silva LCMA, Dantas JKS, Lima MSM, Dantas DV, Dantas RAN. Root cause analysis, failures and effects in pediatric total quality management: a scoping review. Rev Bras Enferm. 2021;74(6):e20200954. https://doi.org/10.1590/0034-7167-2020-0954

Corresponding author: Rodrigo Assis Neves Dantas E-mail: rodrigoenf@yahoo.com.br

EDITOR IN CHIEF: Dulce Barbosa ASSOCIATE EDITOR: Priscilla Broca

Submission: $06-20-2020$

Approval: 03-23-2021

\begin{abstract}
Objectives: to analyze the applicability of Root Cause Analysis and Failure Mode and Effect Analysis tools, aiming to improve care in pediatric units. Methods: this is a scoping review carried out according to the Joanna Briggs Institute guidelines, following the Preferred Reporting Items for Systematic Reviews and Meta-Analyzes extension for Scoping Reviews. Search took place in May 2018 on 15 data sources. Results: search totaled 8,254 studies. After using the relevant inclusion and exclusion criteria, 15 articles were included in the review. Of these, nine were published between 2013 and 2018, 12 used Failure Mode and Effect Analysis and 11 carried out interventions to improve the quality of the processes addressed, showing good post-intervention results. Final Considerations: the application of the tools indicated significant changes and improvements in the services that implemented them, proving to be satisfactory for detecting opportunities for improvement, employing specific methodologies for harm reduction in pediatrics.

Descriptors: Pediatrics; Total Quality Management; Patient Safety; Failure Mode and Effect Analysis; Root Cause Analysis.
\end{abstract}

\section{RESUMO}

Objetivos: analisar a aplicabilidade das ferramentas Análise de Causa Raiz e Análise Modal de Falhas e Efeitos, visando à melhoria da assistência em unidades pediátricas. Métodos: scoping review, realizada conforme orientações do Instituto Joanna Briggs, seguindo o checklist do Preferred Reporting Items for Systematic Reviews and Meta-Analyses extension for Scoping Reviews. A busca ocorreu em maio de 2018 em 15 fontes de dados. Resultados: busca totalizou 8.254 estudos. Após a utilização dos critérios de inclusão e exclusão pertinentes, incluíram-se 15 artigos na revisão. Desses, nove foram publicados entre 2013 e 2018, 12 utilizaram Análise Modal de Falhas e Efeitos e 11 realizaram intervenções para melhoria da qualidade nos processos abordados, mostrando bons resultados pós-intervenções. Considerações Finais: a aplicação das ferramentas indicou mudanças e melhorias significativas nos serviços que as implementaram, mostrando-se satisfatórias para detectar oportunidades de melhorias, empregando metodologias específicas para a redução de danos em pediatria.

Descritores: Pediatria; Gestão da Qualidade Total; Segurança do Paciente; Análise Modal de Falhas e Efeitos; Análise de Causa Raiz.

\section{RESUMEN}

Objetivos: analizar la aplicabilidad de las herramientas Análisis de Causa Raiz y Análisis de Fallas Modales y Efectos, con el objetivo de mejorar la atención en las unidades pediátricas. Métodos: revisión de alcance, realizada de acuerdo con las directrices del Instituto Joanna Briggs, siguiendo la lista de verificación de los Ítems Preferred Reporting Items for Systematic Reviews and Meta-Analyses extension for Scoping Reviews. La búsqueda se realizó en mayo de 2018 en 15 fuentes de datos. Resultados: la búsqueda totalizó 8.254 estudios. Después de utilizar los criterios de inclusión y exclusión relevantes, se incluyeron 15 artículos en la revisión. De estos, nueve fueron publicados entre 2013 y 2018, 12 utilizaron; Análisis de Fallas Modales y Efectos y 11 realizaron intervenciones para mejorar la calidad de los procesos abordados, mostrando buenos resultados post-intervención. Consideraciones Finales: la aplicación de las herramientas indicó cambios y mejoras significativas en los servicios que las implementaron, resultando satisfactorias para detectar oportunidades de mejora, empleando metodologías específicas para la reducción de daños en pediatría. Descriptores: Pediatría; Gestión de la Calidad Total; Seguridad del Paciente; Análisis de Fallas Modales y Efectos; Análisis de Causa Raíz. 


\section{INTRODUCTION}

The macro-complexity of health services and the hospital environment has increasingly inserted technological innovations developed to provide assistance to customers, however these innovations can offer numerous risks to patient safety. Patients' right to quality health care is unquestionable, and it is necessary that, for this, be offered, throughout the care process. a reasoned, competent, safe and adequate health service ${ }^{(1)}$.

Errors are, by definition, unintentional. These are defined as the incorrect performance of an action that was planned, which may contribute to the development of risk to patients' health, defined as the probability of an incident occurring during care provision. Thus, errors can favor the development of incidents, which are events or circumstances that could result, or have resulted, in unnecessary harm to patients(2).

Adverse events are when an incident results in damage to patients. Thus, risk management is important in the search for errors during care, allowing health services to guarantee quality in patient safety through improvement actions ${ }^{(2)}$.

In the context of children's hospitalization, specificities regarding weight, age, stage of development and clinical conditions are involved in the influencing factors in patient safety, with the pediatric public having damage three times greater than adults in a similar situation. Records show that, in a pediatric intensive care unit for cancer care, of 110 medication errors, 71 notifications were recorded, demonstrating the occurrence of 227 errors per 1,000 patients/day ${ }^{(3-4)}$.

Studies on pediatric patient safety indicate the use of tools that improve the safety culture in these institutions, as there are still weaknesses in safe care in pediatric units. For the development of quality management in care, there were increases in quality tools, programs and methods to reduce errors related to health care ${ }^{(5)}$. Among the tools used, we highlight the Root Cause Analysis (RCA) and the Failure Mode and Effect Analysis (FMEA) ${ }^{(6)}$.

RCA is used by many organizations to understand their problems, thus making their recurrences difficult ${ }^{(6-7)}$. Its use in healthcare started in the mid-1990s, being considered mandatory for sentinel hospital events, since 2007, by The Joint Commission (JC) ${ }^{(8)}$.

Therefore, RCA is a systematic and retrospective process, used by a multidisciplinary team that seeks to identify the main causal factors of the failure. This is done through the following methodological path: 1. Identify sentinel events or important events that require an $\mathrm{RCA} ; 2$. Assemble a tea; 3 . Make a diagram of the process: what happened?; 4 . Why did the event happen? Moving from proximity to root causes; 5 . Develop and implement an action plan ${ }^{(9)}$. This tool analyzes the events in a reactive way, looking for the factors that contributed to the occurrence of a certain error, in order to reduce the risks of happening again through the elucidation of the causes and the elaboration of an action plan ${ }^{(8)}$.

FMEA emerged in 1949 in the USA. In 2007, JC considered this tool to be essential for the identification of security risks, being characterized as a tool that makes use of the question "what could go wrong during assistance?" and its consequences before it occurs, that is, it analyzes a high risk process to prevent the occurrence of possible errors in care ${ }^{(8)}$.
FMEA, known in the healthcare sphere as Healthcare Failure Modes and Effects Analysis (HFMEA), is a proactive, systematic, multidisciplinary and preventive risk analysis tool, capable of recognizing problems in the infrastructure before the error occurs. For this, the following methodological path is used: 1. Choose a high-risk process and assemble a team; 2 . Diagram the process; 3. Brainstorming of potential failure modes and ending effects; 4. Prioritize failure modes; 5 . Identify causes of failure modes; 6 . Redesign the process; 7 . Analyze and test the new process; 8. Implement and monitor the redesigned process ${ }^{(10)}$.

Adverse events in the pediatric population are capable of causing irreparable sequelae or even death. Thus, it is necessary to be zealous in the care of pediatric patients through professionals with knowledge about the appropriate techniques in providing care to this population ${ }^{(4,11)}$. Studies state that unsafe processes are due to failures in the planning, collaboration, execution, assessment and monitoring of health care. Therefore, the use of quality management programs, especially in pediatrics, becomes significant ${ }^{(5,12)}$.

Thus, the use of tools, such as FMEA and/or RCA, in the pediatric area, can contribute to the identification of errors related to care, providing information that can assist in the development of measures that ensure the improvement of quality in health services $^{(5,12)}$.

\section{OBJECTIVES}

To analyze the applicability of Root Cause Analysis and Failure Mode and Effect Analysis tools, aiming to improve care in pediatric units.

\section{METHODS}

\section{Type of study}

This is a scoping review. This type of study aims to identify the main scientific evidence on a given topic, highlight existing knowledge gaps, in addition to proposing to clarify the main concepts present in literature ${ }^{(13)}$. The Joanna Briggs Institute Review Manual was used as a theoretical framework for the preparation of the study ${ }^{(13)}$.

\section{Methodological procedures}

This study was registered on the Open Science Framework platform ${ }^{(14)}$, adopting the Preferred Reporting Items for Systematic Reviews and Meta-Analyzes extension for Scoping Reviews (PRISMA-SCR) checklist ${ }^{(15)}$, in order to analyze studies that used RCA and FMEA in pediatric care.

In order to verify scoping reviews or protocols similar to the objective of this study, in May 2018, a search was made on the following platforms: Open Science Framework; JBI Clinical Online Network of Evidence for Care and Therapeutics (COn-

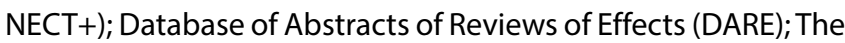
Cochrane Library; International Prospective Register of Ongoing Systematic Reviews (PROSPERO). The search and the results found showed the need to develop studies with the scope of 
analyzing the applicability of RCA and FMEA, aiming to improve care in pediatric units.

For the construction of the research's guiding question, PCC strategy was used, which represents the acronym: Population (Population), Concept (Concept) and Context (Context). In order to construct the research question, the strategy was developed as follows: Population: pediatric patients; Concept: use of RCA and FMEA and the improvement of qualified assistance; Context: pediatric units.

With that, it was questioned: do the applications of RCA and FMEA collaborate for the improvement of qualified care in pediatric units?

\section{Data source}

After the identification and feasibility of the review through a pilot research, as well as the verification of the relevance of the study, we proceeded to choose the databases for the research, which were: 1 . Scopus; 2. Ebsco; 3. SciELO; 4. LILACS; 5 . Web of Science; 6. Medical Literature Analysis and Retrieval System Online (MEDLINE); 7. Cumulative Index to Nursing and Allied Health Literature (CINAHL); 8. Cochrane Library; 9. Science Direct; 10. National Library of Medicine and National Institutes of Health (PubMed); 11. Índice Bibliográfico Español em Ciencias de La Salud (IBECS); 12. Base de Dados de Enfermagem (BDENF); 13. Pan American Health Organization (PAHO); 14. Medical Literature Analysis and Retrieval System Online (WHOLIS); 15. Wiley Online Library. For this, the following search equation was applied: "Pediatrics" AND "Patient safety" AND"Root Cause Analysis"OR"Healthcare Failure Mode and Effect Analysis" OR "Failure Mode and Effect Analysis".

In order to guarantee a high methodological quality, the following inclusion criteria were chosen: scientific articles indexed in the databases mentioned above, that addressed the application of RCA and FMEA in pediatrics and that met $60 \%$ of the criteria established from an adaptation of Standards for Quality Improvement Reporting Excellence (SQUIRE 2.0) ${ }^{(4)}$. Documents written in English, Brazilian Portuguese, Spanish, Italian or French were also selected, with no year restrictions during the search for articles.

To complement the electronic search, the bibliographic references of the included articles were checked and, when pertinent, selected for the present study. Exclusion criteria were review articles, editorials, letters to the editor, abstracts and expert opinion, who did not work RCA and FMEA in the field of pediatrics or who did not meet the established percentage of SQUIRE 2.0.

The bibliographic search was carried out by two researchers. Any questions or discrepancies were agreed upon during the research team meetings. Each researcher conducted a search using the same data sources and the same descriptors in the month of May/2018, however, in separate locations, in order to avoid bias during the research. All researchers were previously trained on the inclusion/exclusion and handling criteria in the data sources, to ensure standardization and adequate selection of articles.

\section{Data analysis}

In the first stage, article refinement, titles and abstracts of all articles found during the searches were read, remaining only those pertinent to the researched topic. Subsequently, in the second stage, the duplicate titles were removed and the full reading of the articles was performed, together with the extraction of significant data, such as place of study, target audience and the type of tool used (RCA or FMEA). After full reading, research was selected to be included in the qualitative analysis of studies (third stage).

Therefore, the third stage was carried out from an adaptation of the SQUIRE 2.0 protocol. This protocol presents revised standards, to cite new competencies on quality improvement, through a guidance guide. This instrument was selected so that study analysis could be developed in a resolute way, through the competence of items covered in the articles.

An adapted version of SQUIRE 2.0 was used, in which quality criteria were constructed regarding the title, summary, introduction, results and discussion, applied in the analysis of the articles. The original protocol consists of 18 items, some of which are divided into sub-items, completing a total of 40 recommendations. The final version, adapted and summarized, was finalized, with 21 criteria to be applied in each selected article, the score being: total compliance $=1$ point; partial $=0.5$ point; non-compliance $=0$ point $^{(4)}$.

The 21 criteria to be considered in each study are: 1 . Title - indicates that the article concerns an initiative to improve health; 2. Abstract - provides the key information of the text sections and in the structured summary format; 3 . Problem description describes the nature and importance of the problem; 4. Available knowledge - presents a summary of what literature currently brings about the problem; 5. Objectives - presents research objectives; 6 . Method 1- describes the tool and its steps in sufficient detail for others to reproduce it; 7. Method 2 - specifies the team involved in the work, detailing its components; 8 . Indicators - uses indicators or criteria to analyze the intervention processes and results through the tool use; 9 . Analysis - uses qualitative and/ or quantitative methods to draw conclusions from the data; 10. Ethical considerations - informs formal ethical reviews and/or potential conflicts of interest ${ }^{(4)}$.

The criteria: 11. Result 1 - presents the initial steps of the tool and its evolution over time, including modifications; 12. Result 2 - presents the details of the process and result (measures); 13 . Result 3 - reports factors from the local context that interfered with the interventions; 14 . Result 4 - has unintended consequences: unexpected benefits, problems, failures or costs; 15. Discussion - presents strengths of the work, including the relevance for justifying the work and the objective; 16 . Interpretation - demonstrates the association (relationship) between the intervention and the results; 17 . Interpretation 1 - compares the results with the findings of other publications; 18 . Interpretation 2 - highlights the impact of the project on people and health systems; 19. Limitations - presents limits for the generalization of work; 20. Limitations 1 - presents confounding factors (bias or imprecision in the methods or analysis) and reports the efforts to make these limitations inimical; 21 . Conclusion - highlights the usefulness and sustainability of the work as well as the potential for spread and other contexts ${ }^{(4)}$.

Meetings were held to standardize those involved in the study, through debates about the researched tools, interpretation of each topic adapted from SQUIRE 2.0, as well as the pilot use of 
the instrument to an article, in order to reduce the subjectivity capable of causing bias in the development and results of this study.

The assessment of each article was carried out by two researchers in an impartial and blind manner. Subsequently, the scores of each criterion were compared and, in the event of incompatibilities, a third evaluator was asked for the final agreement of the score. In order to calculate the agreement between the examiners, it was decided to use Kappa index, which obtained a value of 0.97 , corresponding to an excellent agreement ${ }^{(11)}$. For this calculation, the 15 articles and 21 items adapted from SQUIRE 2.0 were considered, totaling 315 items assessed.

\section{RESULTS}

The search in the databases resulted in 8,254 articles (Figure 1), through the journals portal of the Coordination for the Improvement of Higher Education Personnel (CAPES - Coordenação de Aperfeiçoamento de Pessoal de Nível Superior) and the Virtual Health Library (VHL), divided into the following databases: 549 at Scopus, 284 at Ebsco, 21 at SciELO, 629 at Web of Science, 267 at MEDLINE, 89 at CINAHL, 4 at Cochrane Library, 1,765 at Science Direct, 284 at PubMed, 25 at IBECS, 07 at BDENF and 4330 Wiley Online Library. No articles were found in the PAHO, WHOLIS and LILACS databases.

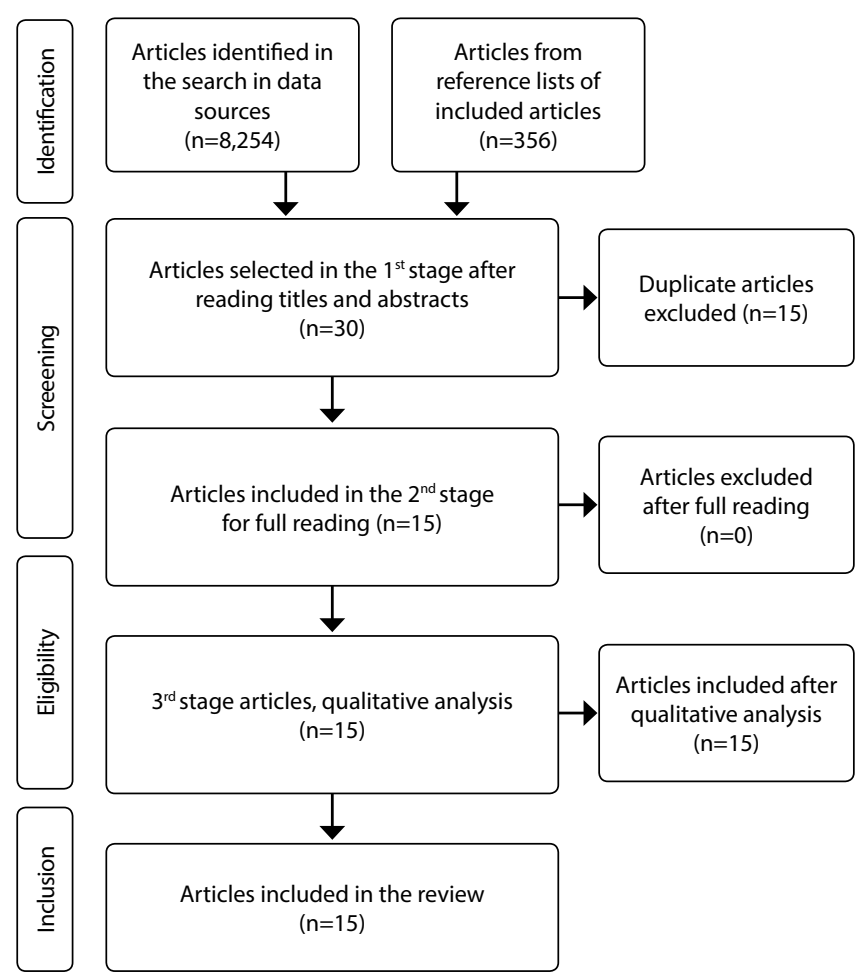

Figure 1- Flowchart of identification and selection of articles for scoping review on Root Cause Analysis and Failure Mode and Effect Analysis in Pediatric Units, based on the guidelines of PRISMA-ScR (adapted), 2018

In the first stage, 30 articles were selected, of which 15 were excluded because they were duplicated in the databases. After full reading (second stage) of the other 15 selected articles, it was noticed that the inclusion criteria were fully fulfilled, without the need to exclude any of the articles. Subsequently, they were analyzed in the qualitative stage.
The results in the studies' qualitative analysis (Table 1), through the adapted SQUIRE 2.0, enabled the determination of global scores.

Table 1- Scoring in descending order of the 15 articles assessed through the adapted SQUIRE 2.0 and definition of the cut-off point for the inclusion of articles in the scoping review. Natal, Rio Grande do Norte, Brazil, 2018

\begin{tabular}{|c|c|c|c|}
\hline $\mathbf{N}^{\circ}$ & Articles & Total score & $\%$ \\
\hline 1 & Van Tilburg et al., 2006 ${ }^{(16)}$ & 20 & 95.23 \\
\hline 2 & Martin et al., $2017^{(17)}$ & 19 & 90.47 \\
\hline 3 & Daverio et al., $2015^{(18)}$ & 19 & 90.47 \\
\hline 4 & Rodríguez et al., 2014(19) & 18 & 85.71 \\
\hline 5 & Lago et al., $2012^{(20)}$ & 18 & 85.71 \\
\hline 6 & Berruyer et al., 2016 (21) & 17 & 80.95 \\
\hline 7 & Dehnavieh et al., $2015^{(22)}$ & 17 & 80.95 \\
\hline 8 & Apkon et al., 2004 & 16.5 & 78.57 \\
\hline 9 & Robinson et al., 2006 (24) & 15.5 & 73.80 \\
\hline 10 & Babiker et al., 2017 (25) & 15 & 71.42 \\
\hline 11 & Jayashree et al., $2017^{(26)}$ & 14.5 & 69.04 \\
\hline 12 & Bonnabryet al., $2005^{(27)}$ & 13.5 & 64.28 \\
\hline 13 & Morse et al., $2011^{(28)}$ & 13.5 & 64.28 \\
\hline 14 & Tija et al., 2014 (29) & 13 & 61.90 \\
\hline 15 & Bhalla et al., 2012(30) & 13 & 61.90 \\
\hline
\end{tabular}

For the inclusion of the articles, the goal of meeting at least $60 \%$ of the criteria was established, that is, the total score of at least 13 points out of the 21 that appear in the adapted SQUIRE 2.0. In view of this, after performing the relevant calculations (Table 1), the 15 articles remained to compose this review ${ }^{(16-30)}$. Of these, nine resulted from the Scopus database $\mathrm{e}^{(16-17,19-21,24,26,29)}$.

Chart 1 presents a summary of selected studies, specifying the author and year of publication, country of study, type of pediatric unit, the tool used to improve quality and their respective bibliographic references, the objective of the study, the methodological trajectory covered in the use of tools, interventions performed, as well as improvement indicators and their results.

Among the 15 articles selected, eight were published between 2013 and $2018^{(17-19,21-22,25-26,29)}$. The others seven studies had been published in $2012^{(20,30)}, 2011^{(28)}, 2006^{(16,24)}, 2005^{(27)}$ and $2004^{(23)}$.

The USA developed six of the 15 selected studies ${ }^{(17,23-24,28-31)}$. The other nine studies were conducted in India ${ }^{(26)}$, Canada $^{(21)}$, Spain $^{(19)}$, Italy ${ }^{(18,20)}$, Netherlands ${ }^{(16)}$, Iran ${ }^{(22)}$, Switzerland ${ }^{(27)}$ and Saudi Arabia ${ }^{(25)}$. Regarding the characteristics of pediatric units, ten studies were

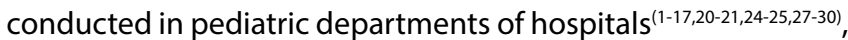
three in Pediatric Intensive Care Units (PICU) $)^{(18-19,23)}$ and two in emergencies ${ }^{(19,26)}$.

Regarding the tool used, 12 used the FMEA ${ }^{(16-25,27,30)}$ and three used $\mathrm{RCA}^{(26,28-29)}$.

The themes addressed through the tools were diabetic ketoacidosis $^{(26)}$, process in the use of drugs ${ }^{(17,20-21,23)}$, use of continuous drug infusion pumps ${ }^{(19)}$, safety in anesthetic care ${ }^{(29)}$, chemotherapy administration $^{(16,24)}$, blood transfusion ${ }^{(22)}$, parenteral nutrition ${ }^{(27)}$, use of pediatric catheters ${ }^{(30)}$, trends in critical incidents $(\mathrm{Cl})$ in the trend and severity of medical errors ${ }^{(18)}$, implementation of clinical practice guidelines $^{(17)}$, and monitoring the forces of action plans ${ }^{(28)}$.

Of the 15 articles selected, 11 performed interventions to improve quality in the processes addressed, showing good post-intervention results ${ }^{(16-17,19-21,23-25,27-28,30)}$. Of the 11 studies, only one did not use indicators to measure improvement; however, it showed that the tool and the proposed interventions were effective in giving confidence to professionals ${ }^{(30)}$. 
Chart 1 - Extraction of data from the 15 articles selected for the scoping review referring to author/year of publication, country, type of pediatric unit, tool and references, objective, methodological trajectory, interventions performed and improvement indicators

\begin{tabular}{|c|c|c|c|c|c|c|c|c|}
\hline No & $\begin{array}{c}\text { AUTHOR/ } \\
\text { YEAR }\end{array}$ & COUNTRY & $\begin{array}{l}\text { PEDIATRIC } \\
\text { UNIT TYPE } \\
\end{array}$ & $\begin{array}{l}\text { TOOL AND } \\
\text { REFERENCE }\end{array}$ & OBJECTIVE & $\begin{array}{l}\text { METHODOLOGICAL } \\
\text { TOOL PATH }\end{array}$ & $\begin{array}{l}\text { INTERVENTIONS } \\
\text { CARRIED OUT }\end{array}$ & $\begin{array}{l}\text { IMPROVEMENT } \\
\text { INDICATORS } \\
\end{array}$ \\
\hline 1 & \begin{tabular}{|} 
Van Tilburg \\
et al., \\
$2006^{(16)}$
\end{tabular} & Netherlands & $\begin{array}{c}\text { Pediatric } \\
\text { Oncology Unit }\end{array}$ & $\begin{array}{c}\text { FMEA } \\
\text { DeRosier et al., } \\
2002^{(31)}\end{array}$ & $\begin{array}{l}\text { Investigate whether } \\
\text { HFMEA is valid for } \\
\text { analyzing health } \\
\text { care processes, such } \\
\text { as chemotherapy } \\
\text { administration in a } \\
\text { pediatric oncologi- } \\
\text { cal hospitalization } \\
\text { environment. }\end{array}$ & $\begin{array}{l}\text { 1Team assembly; } \\
\text { 2. Flow diagram; } \\
\text { 3. Risk analysis; } \\
\text { 4. Actions of the } \\
\text { process results. }\end{array}$ & $\begin{array}{l}\text { 1. Changes in treat- } \\
\text { ment schedules; } \\
\text { 2. Chemotherapy } \\
\text { schedules; } \\
\text { 3. Determine the } \\
\text { minimum number } \\
\text { of residents; } \\
\text { 4. Prescription of } \\
\text { chemotherapy re- } \\
\text { quests by residents. }\end{array}$ & $\begin{array}{l}\text { 1. Professionals' } \\
\text { satisfaction about } \\
\text { utility, expecta- } \\
\text { tions, time plan- } \\
\text { ning, participa- } \\
\text { tion of parents/ } \\
\text { patients. }\end{array}$ \\
\hline 2 & \begin{tabular}{|} 
Martin et \\
al., $2017^{(17)}$
\end{tabular} & USA & $\begin{array}{c}\text { Children's } \\
\text { academic } \\
\text { hospital }\end{array}$ & $\begin{array}{c}\text { FMEA } \\
\text { Chang et al., } \\
2012^{(32)}\end{array}$ & $\begin{array}{l}\text { Analyze FMEA in the } \\
\text { practice of medica- } \\
\text { tion performed in the } \\
\text { operating room of } \\
\text { a children's hospital, } \\
\text { assessing each stage } \\
\text { of the treatment pro- } \\
\text { cess, scoring possible } \\
\text { failures and risks. }\end{array}$ & $\begin{array}{l}\text { 1. Team set-up; } \\
\text { 2. Flow definition; } \\
\text { 3. Determination of } \\
\text { "failure modes"; } \\
\text { 4. Risk priority num- } \\
\text { ber (RPN) of failures } \\
\text { 5. Interventions for } \\
\text { those with the high- } \\
\text { est RPN. }\end{array}$ & $\begin{array}{l}\text { 1. Reorganization } \\
\text { of the medication } \\
\text { tray; } \\
\text { 2. Top model of } \\
\text { medication cart; } \\
\text { 3. Syringe labelling; } \\
\text { 4. Double infusion } \\
\text { check; } \\
\text { 5. Medication prac- } \\
\text { tice guideline. }\end{array}$ & $\begin{array}{l}\text { Use of charts with } \\
\text { failure scores and } \\
\text { effects before } \\
\text { and after the } \\
\text { applied interven- } \\
\text { tions. }\end{array}$ \\
\hline 3 & $\begin{array}{l}\text { Daverio et } \\
\text { al., } 2015^{(18)}\end{array}$ & Italy & PICU & $\begin{array}{c}\text { FMEA } \\
\text { Reference not } \\
\text { mentioned }\end{array}$ & $\begin{array}{l}\text { Describe the tenden- } \\
\text { cy of Cl in PICU over a } \\
\text { period of } 4 \text { years and } \\
\text { assess the } \\
\text { effect of FMEA ap- } \\
\text { plication on the ten- } \\
\text { dency and severity of } \\
\text { medical errors. }\end{array}$ & $\begin{array}{l}\text { 1. Process selection; } \\
\text { 2. Team selection; } \\
\text { 3. Design of the } \\
\text { process } \\
\text { 4. Failure and effect } \\
\text { identification; } \\
\text { 5. Numeric value to } \\
\text { identify weaknesses; } \\
\text { 6. Improvement } \\
\text { strategies. }\end{array}$ & Not performed. & $\begin{array}{l}\text { 1. } 165 \% \text { increase } \\
\text { in report produc- } \\
\text { tion; } \\
\text { 2. Decrease in the } \\
\text { severity of errors. }\end{array}$ \\
\hline 4 & \begin{tabular}{|} 
Rodríguez \\
et al., \\
$2014^{(19)}$
\end{tabular} & Spain & PICU & $\begin{array}{c}\text { FMEA } \\
\text { Joint } \\
\text { Commission on } \\
\text { Accreditation } \\
\text { of Healthcare } \\
\text { Organizations } \text { s }^{(33)}\end{array}$ & $\begin{array}{l}\text { Carry out FMEA on } \\
\text { the risks in the use } \\
\text { of intelligent infu- } \\
\text { sion pumps in PICU } \\
\text { before and after the } \\
\text { implementation of } \\
\text { the devices to iden- } \\
\text { tify improvement } \\
\text { actions. }\end{array}$ & $\begin{array}{l}\text { 1. Team assembling; } \\
\text { 2. Identify risks at } \\
\text { different stages; } \\
\text { 3. Qualitative analysis } \\
\text { of failure cause and } \\
\text { effect; } \\
\text { 4. Quantitative analy- } \\
\text { sis for each error; } \\
\text { 5. Actions to mini- } \\
\text { mize the probability } \\
\text { of occurrence. }\end{array}$ & $\begin{array}{l}\text { Conducting peri- } \\
\text { odic reviews of the } \\
\text { medicines library, } \\
\text { developing sup- } \\
\text { porting documents } \\
\text { and including } \\
\text { training. After } 18 \\
\text { months, smart } \\
\text { pump technology } \\
\text { was introduced } \\
\text { into PICU. }\end{array}$ & $\begin{array}{l}\text { Use of the Guard- } \\
\text { railsR CQI v4.1 } \\
\text { Event Reporter } \\
\text { Software }\end{array}$ \\
\hline 5 & $\begin{array}{l}\text { Lago } \\
\text { et al., } \\
2012^{(20)}\end{array}$ & Italy & $\begin{array}{l}\text { Pediatric } \\
\text { hospital }\end{array}$ & $\begin{array}{l}\text { FMEA } \\
\text { Reference is not } \\
\text { mentioned. }\end{array}$ & $\begin{array}{l}\text { Examine the dangers } \\
\text { associated with the } \\
\text { drug delivery process } \\
\text { to children by } \\
\text { conducting a proac- } \\
\text { tive risk assessment } \\
\text { analysis. }\end{array}$ & $\begin{array}{l}\text { 1. Team set-up; } \\
\text { 2. Flow diagrams; } \\
\text { 3. Highlight possible } \\
\text { sources of errors; } \\
\text { 4. Reason for failure; } \\
\text { 5. Quantify the sever- } \\
\text { ity of the effects; } \\
\text { 6. Risk reduction } \\
\text { strategy. }\end{array}$ & $\begin{array}{l}\text { 1. Preprint label for } \\
\text { patient identifica- } \\
\text { tion; new way of } \\
\text { reordering medi- } \\
\text { cines; quiet place } \\
\text { to prepare recipes; } \\
\text { active ingredi- } \\
\text { ent prescription; } \\
\text { prescription with } \\
\text { understandable } \\
\text { writing; } \\
\text { 2. Clinical audits. } \\
\end{array}$ & $\begin{array}{l}\text { RPN values } \\
\text { before and after } \\
\text { interventions. }\end{array}$ \\
\hline 6 & $\begin{array}{c}\text { Berruyer et } \\
\text { al., 2016 }\end{array}$ & Canada & $\begin{array}{l}\text { Installation of } \\
\text { parents and } \\
\text { children of } \\
\text { the University } \\
\text { Hospital of } \\
\text { Montreal }\end{array}$ & $\begin{array}{c}\text { FMEA } \\
\text { Institute of Safe } \\
\text { Medication } \\
\text { Practices }^{(34)}\end{array}$ & $\begin{array}{l}\text { Assess the risks as- } \\
\text { sociated with insulin } \\
\text { use in a health unit } \\
\text { and propose an } \\
\text { action plan to reduce } \\
\text { the main risks associ- } \\
\text { ated with failures. }\end{array}$ & $\begin{array}{l}\text { 1. Classification of the } \\
\text { failure mode grid by } \\
\text { a team; } \\
\text { 2. Calculation of } \\
\text { criticality indexes; } \\
\text { 3. Approval of clas- } \\
\text { sifications; } \\
\text { 4. Data analysis. }\end{array}$ & $\begin{array}{l}\text { 1. Audit; } \\
\text { 2. Update service } \\
\text { appropriations with } \\
\text { insulin; } \\
\text { 3. Reassessment } \\
\text { of dispensation } \\
\text { policy; } \\
\text { 5. Raise caregivers' } \\
\text { awareness. }\end{array}$ & $\begin{array}{l}\text { Assessment of } \\
\text { criticality indexes. }\end{array}$ \\
\hline
\end{tabular}




\begin{tabular}{|c|c|c|c|c|c|c|c|c|}
\hline No & $\begin{array}{l}\text { AUTHOR/ } \\
\text { YEAR }\end{array}$ & COUNTRY & $\begin{array}{l}\text { PEDIATRIC } \\
\text { UNIT TYPE }\end{array}$ & $\begin{array}{l}\text { TOOL AND } \\
\text { REFERENCE }\end{array}$ & OBJECTIVE & $\begin{array}{l}\text { METHODOLOGICAL } \\
\text { TOOL PATH }\end{array}$ & $\begin{array}{l}\text { INTERVENTIONS } \\
\text { CARRIED OUT }\end{array}$ & $\begin{array}{l}\text { IMPROVEMENT } \\
\text { INDICATORS }\end{array}$ \\
\hline 7 & $\begin{array}{c}\text { Dehnavieh } \\
\text { et al., } \\
2015^{(22)}\end{array}$ & Iran & $\begin{array}{c}\text { Pediatric } \\
\text { Emergency } \\
\text { Department }\end{array}$ & $\begin{array}{c}\text { FMEA } \\
\text { (HFMEA) } \\
\text { Cheng et al, } \\
2012^{(35)}\end{array}$ & $\begin{array}{l}\text { Assess the risk in the } \\
\text { blood transfusion } \\
\text { process in a pediatric } \\
\text { emergency through } \\
\text { the FMEA tool. }\end{array}$ & $\begin{array}{l}\text { 1. Team meeting; } \\
\text { 2. Flow diagram } \\
\text { 3. Harm analysis in } 04 \\
\text { phases; } \\
\text { 4. Measure of action; } \\
\text { 4.1. Action descrip- } \\
\text { tion; } 4.2 \text {. Process } \\
\text { redesign. }\end{array}$ & Not performed. & Not mentioned. \\
\hline 8 & $\begin{array}{l}\text { Apkon et } \\
\text { al., 2004 }\end{array}$ & USA & PICU & $\begin{array}{c}\text { FMEA } \\
\text { Grissinger et al., } \\
2002^{(36)} \\
\text { (Joint }^{\text {Commission on }} \\
\text { Accreditation } \\
\text { of Healthcare } \\
\text { Organizations) }\end{array}$ & $\begin{array}{l}\text { Administer con- } \\
\text { tinuous infusions, } \\
\text { improving patient } \\
\text { safety, team, hemo- } \\
\text { dynamic stability } \\
\text { during infusion and } \\
\text { efficient use of } \\
\text { resources. }\end{array}$ & $\begin{array}{l}\text { 1. Characterize } \\
\text { process steps; } \\
\text { 2. Identify failure } \\
\text { modes; } \\
\text { 3. RPN calculation; } \\
\text { 5. Corrective mea- } \\
\text { sures for elements } \\
\text { with the highest RPN. }\end{array}$ & $\begin{array}{l}\text { 1. Standard formu- } \\
\text { lations; } \\
\text { 2. Calculators for } \\
\text { multiple comput- } \\
\text { ing platforms; } \\
\text { 4. Prefabricated } \\
\text { purchase and stock; } \\
\text { 5. Change the } \\
\text { responsibility for } \\
\text { the pharmacy } \\
\text { preparation. }\end{array}$ & $\begin{array}{l}\text { 1. Team satisfac- } \\
\text { tion; } \\
\text { 2. RPN assess- } \\
\text { ment, severity (S), } \\
\text { occurrence }(O) \\
\text { and detection (D) } \\
\text { values before and } \\
\text { after corrective } \\
\text { measures. }\end{array}$ \\
\hline 9 & $\begin{array}{l}\text { Robinson } \\
\text { et al., } \\
2006^{(24)}\end{array}$ & USA & $\begin{array}{c}\text { Pediatric } \\
\text { Oncology Unit }\end{array}$ & $\begin{array}{c}\text { FMEA } \\
\text { (HFMEA) } \\
\text { Adachi W, } \\
\text { Lodolce A, } \\
2005^{(37)}\end{array}$ & $\begin{array}{l}\text { Use FMEA to identify } \\
\text { appropriate risks and } \\
\text { strategies in the } \\
\text { administration of } \\
\text { chemotherapy in } \\
\text { children. }\end{array}$ & $\begin{array}{l}\text { 1. Data collection; } \\
\text { 3. Flowchart; } \\
\text { 4. Failure points and } \\
\text { the cause. } \\
\text { 5. Identify the cause; } \\
\text { 6. Strategies to } \\
\text { reduce risks. }\end{array}$ & $\begin{array}{l}\text { The team made } \\
\text { and implemented } \\
\text { the recommenda- } \\
\text { tions in the process } \\
\text { of medication } \\
\text { prescription and } \\
\text { administration. }\end{array}$ & $\begin{array}{l}\text { Comparison of } \\
\text { the percentages } \\
\text { of prescription } \\
\text { error, medication } \\
\text { dispensing and } \\
\text { administration. }\end{array}$ \\
\hline 10 & $\begin{array}{l}\text { Babiker et } \\
\text { al., 2017 (25) }\end{array}$ & $\begin{array}{l}\text { Saudi } \\
\text { Arabia }\end{array}$ & $\begin{array}{l}\text { Department } \\
\text { of Pediatrics, } \\
\text { King Khalid } \\
\text { University } \\
\text { Hospital }\end{array}$ & $\begin{array}{c}\text { FMEA } \\
\text { IHIWorkspace } \\
\text { online }^{(38)}\end{array}$ & $\begin{array}{l}\text { Provide an accurate } \\
\text { assessment of the } \\
\text { occurrence and } \\
\text { frequency of failures } \\
\text { and their effects on } \\
\text { clinical practice. }\end{array}$ & $\begin{array}{l}\text { 1. Team assembling; } \\
\text { 2. Training on FMEA; } \\
\text { 3. Data collection; } \\
\text { 4. Identification of } \\
\text { potential failures; } \\
\text { 5. Score for each } \\
\text { attribute item; } \\
\text { 6. The number of } \\
\text { risk priorities was } \\
\text { calculated. }\end{array}$ & $\begin{array}{l}\text { 1. Regular audit; } \\
\text { 2. Improvement } \\
\text { of Clinical Practice } \\
\text { Guidelines (CPG); } \\
\text { 3. Quality improve- } \\
\text { ment; } \\
\text { 4. Organization of } \\
\text { awareness-raising } \\
\text { activities; } \\
\text { 5. Availability of } \\
\text { printed or elec- } \\
\text { tronic materials; }\end{array}$ & $\begin{array}{l}\text { 1. Number of } \\
\text { adapted CPGs } \\
\text { finalized; } \\
\text { 2. Number } \\
\text { of general } \\
\text { awareness-rais- } \\
\text { ing sessions; } \\
\text { 3. Number of } \\
\text { educational ses- } \\
\text { sions; } \\
\text { 4. Percentage } \\
\text { of patients who } \\
\text { achieved the } \\
\text { results. }\end{array}$ \\
\hline 11 & $\begin{array}{l}\text { Jayashree } \\
\text { et al., } \\
2017^{(26)}\end{array}$ & India & $\begin{array}{l}\text { Emergency } \\
\text { department }\end{array}$ & $\begin{array}{l}\text { RCA } \\
\text { ledema et al., } \\
2006^{(39)}\end{array}$ & $\begin{array}{l}\text { Identify factors } \\
\text { contributing to } \\
\text { admissions to the } \\
\text { Emergency Depart- } \\
\text { ment (ED) of children } \\
\text { with diabetic } \\
\text { ketoacidosis, with } \\
\text { emphasis on aware- } \\
\text { ness of parents, the } \\
\text { doctor and prenatal } \\
\text { management. }\end{array}$ & $\begin{array}{l}\text { 1. Theme discussion; } \\
\text { 2. Questionnaire } \\
\text { formulation; } \\
\text { 3. Preparation } \\
\text { of a causal factor } \\
\text { diagram; } \\
\text { 4. Identification of } \\
\text { complications, their } \\
\text { causes and effects; } \\
\text { 5. Use of descriptive } \\
\text { statistics of the data } \\
\text { found. }\end{array}$ & Not performed. & Not mentioned. \\
\hline 12 & $\begin{array}{l}\text { Bonnabry } \\
\text { et al., } \\
2005^{(27)}\end{array}$ & Switzerland & $\begin{array}{l}\text { Pediatric } \\
\text { hospital }\end{array}$ & $\begin{array}{c}\text { FMEA } \\
\text { McDonough, } \\
2003^{(40)}\end{array}$ & $\begin{array}{l}\text { Compare the risks } \\
\text { associated with old } \\
\text { and new processes } \\
\text { to quantify improved } \\
\text { safety with the new } \\
\text { process and iden- } \\
\text { tify risks to improve } \\
\text { safety in the produc- } \\
\text { tion of pediatric } \\
\text { parenteral nutrition } \\
\text { solutions. }\end{array}$ & $\begin{array}{l}\text { 1. Team assembling; } \\
\text { 2. Definition of } \\
\text { process stages; } \\
\text { 3. Brainstorming; } \\
\text { 4. Cause-effect } \\
\text { diagram; } \\
\text { 5. Comparison of the } \\
\text { two methods }\end{array}$ & $\begin{array}{l}\text { Implementation } \\
\text { of integrated } \\
\text { access software, in } \\
\text { order to guide the } \\
\text { prescribing physi- } \\
\text { cian and connect } \\
\text { the prescription } \\
\text { process directly } \\
\text { to the production } \\
\text { process, including } \\
\text { pharmaceutical } \\
\text { validation, labeling } \\
\text { and composition. }\end{array}$ & $\begin{array}{l}\text { The sum of } \\
\text { Cls from all } 18 \\
\text { identified failure } \\
\text { modes was } 3,415 \\
\text { for the old pro- } \\
\text { cess and 1,397 } \\
\text { for the new one } \\
\text { (59\% reduction). }\end{array}$ \\
\hline
\end{tabular}




\begin{tabular}{|c|c|c|c|c|c|c|c|c|}
\hline No & $\begin{array}{l}\text { AUTHOR/ } \\
\text { YEAR }\end{array}$ & COUNTRY & $\begin{array}{l}\text { PEDIATRIC } \\
\text { UNIT TYPE }\end{array}$ & $\begin{array}{l}\text { TOOL AND } \\
\text { REFERENCE }\end{array}$ & OBJECTIVE & $\begin{array}{l}\text { METHODOLOGICAL } \\
\text { TOOL PATH }\end{array}$ & $\begin{array}{l}\text { INTERVENTIONS } \\
\text { CARRIED OUT }\end{array}$ & \begin{tabular}{|l} 
IMPROVEMENT \\
INDICATORS
\end{tabular} \\
\hline 13 & $\begin{array}{l}\text { Morse et } \\
\text { al., 2011(28) }\end{array}$ & USA & $\begin{array}{l}\text { Pediatric } \\
\text { hospital }\end{array}$ & $\begin{array}{c}\text { RCA } \\
\text { The Joint } \\
\text { Commission, } \\
2009^{(41)}\end{array}$ & $\begin{array}{l}\text { Establish a reference } \\
\text { point to monitor the } \\
\text { strength of action } \\
\text { plans developed } \\
\text { through RCA and its } \\
\text { execution rates. }\end{array}$ & $\begin{array}{l}\text { 1. Each RCA was } \\
\text { analyzed by the Di- } \\
\text { rector of the Quality } \\
\text { Department; } \\
\text { 2. Actions developed } \\
\text { to address each } \\
\text { individual event were } \\
\text { classified as weak, in- } \\
\text { termediate or strong, } \\
\text { using the recom- } \\
\text { mended hierarchy of } \\
\text { actions. }\end{array}$ & $\begin{array}{l}\text { 1. Improvement } \\
\text { in documentation } \\
\text { and communica- } \\
\text { tion; } \\
\text { 2. Software im- } \\
\text { provement in the } \\
\text { entry of computer- } \\
\text { ized requests; } \\
\text { 3. Reduce distrac- } \\
\text { tions; } \\
\text { 4. Standardize } \\
\text { processes; } \\
\text { 5. Continued train- } \\
\text { ing; } \\
\text { 6. Analyze and } \\
\text { inspect equipment. }\end{array}$ & $\begin{array}{l}\text { Comparison of } \\
\text { the implementa- } \\
\text { tion of the ac- } \\
\text { tions developed } \\
\text { as a result of } \\
\text { RCAs with previ- } \\
\text { ous studies. }\end{array}$ \\
\hline 14 & $\begin{array}{l}\text { Tjiaet al., } \\
2014^{(29)}\end{array}$ & USA & $\begin{array}{l}\text { Pediatric } \\
\text { hospital }\end{array}$ & $\begin{array}{l}\text { RCA } \\
\text { The Joint } \\
\text { Commission, } \\
\text { 20099(41) }\end{array}$ & $\begin{array}{l}\text { Implement changes } \\
\text { in care processes } \\
\text { that improve the } \\
\text { quality and safety } \\
\text { of anesthetic care } \\
\text { provided to pediatric } \\
\text { patients throughout } \\
\text { the country. }\end{array}$ & $\begin{array}{l}\text { 1. Questions to } \\
\text { analyze and identify } \\
\text { system failures; } \\
\text { 2. Team members; } \\
\text { 3. Recommendations; } \\
\text { 4. Action plan follow } \\
\text { up. }\end{array}$ & Not performed. & Not mentioned. \\
\hline 15 & $\begin{array}{l}\text { Bhalla et } \\
\text { al., 2012(30) }\end{array}$ & USA & $\begin{array}{l}\text { Department of } \\
\text { Anesthesiology } \\
\text { of Nationwide } \\
\text { Children's } \\
\text { Hospital }\end{array}$ & $\begin{array}{c}\text { FMEA } \\
\text { (HFMEA) } \\
\text { Reference is not } \\
\text { mentioned }\end{array}$ & $\begin{array}{l}\text { Identify failure } \\
\text { modes and their } \\
\text { causes and effects on } \\
\text { the use of peripheral } \\
\text { catheters. }\end{array}$ & $\begin{array}{l}\text { 1. Multidisciplinary } \\
\text { team assembling; } \\
\text { 2. Follow-up meet- } \\
\text { ings and interroga- } \\
\text { tions; } \\
\text { 3. Describe the pro- } \\
\text { cess using process } \\
\text { flow maps; } \\
\text { 4. Identify potential } \\
\text { failure modes related } \\
\text { to each step of the } \\
\text { process. }\end{array}$ & $\begin{array}{l}\text { 1. Home-going } \\
\text { instructions; } \\
\text { 2. Design of new la- } \\
\text { bels for pain pump } \\
\text { and piping; } \\
\text { 3. Design of an } \\
\text { electronic order-set; } \\
\text { 4. Changes to } \\
\text { pharmacy code } \\
\text { kits, as well as the } \\
\text { modification of } \\
\text { hand-offs between } \\
\text { services. }\end{array}$ & Not mentioned. \\
\hline
\end{tabular}

The information acquired after the implementation of these tools is able to encourage pediatric institutions to start discussions on risk trends, resulting in the formulation of plans to reduce them on a national scale and not only locally ${ }^{(29)}$. Chart 1 shows the categorization of improvement indicators is observed after the application of these tools.

\section{DISCUSSION}

In this scoping review, $53.3 \%$ of articles were from the last 6 years $^{(17-20,22,25-26,29)}$, noting a current temporality of studies, the relevance of this review and the recent application of RCA and FMEA tools in pediatric units. FMEA was characterized as the quality tool chosen in most of the articles of this review (80\%), being used mainly in studies developed in the USA ${ }^{(17,23-24,28-30)}$.

None of the included articles was developed in Brazil. This fact denotes the low number of scientific studies using FMEA and RCA in health research in the country, although the Brazilian National Patient Safety Program (PNSP - Programa Nacional de Segurança do Paciente) encourages and demonstrates the importance of these tools for analysis of errors and, consequently, related incidents patient safety ${ }^{(31)}$.

A research on the applicability of these tools, developed in the ICU ${ }^{(18-19,23)}$, is justified by the various factors that make patients, especially pediatric ones, more vulnerable to errors, among them the complexity of care, highlighting medication administration, in addition to the vulnerability of patients' critical conditions ${ }^{(11,32)}$.

The topic of drug therapy is one of the most talked about when talking about patient safety and, in the case of children, the administration of drugs needs to be judicious, with an important requirement from the health team, given the specifics in relation to child's age, weight, body surface area, absorption capacity, biotransformation and drug excretion ${ }^{(32-33)}$.

Another research carried out in Southern Brazil showed risk situations in pediatric inpatient units after profiling their reports, finding errors associated with the conduct of unnecessarily fasting children, failures in identifying pediatric patients, administrative factors, in addition to associated with medication and allergy caused by wristbands. In this regard, health professionals must commit to promoting the health of this population, guaranteeing their rights during care provision ${ }^{(34)}$.

A study carried out at the PICU of a university hospital in Italy showed that the use of FMEA increased the reporting rates of incidents related to drug therapy, with a consequent decrease in the severity of errors made, thanks to the improved action plans after using the tool. The authors of this research stated that FMEA was much more than a tool used to avoid errors, i.e., it was also able to change the mentality of the hospital's clinical 
team, increasing awareness that there is a problem and the need to do something to correct them ${ }^{(18)}$.

All selected articles, which were developed at PICU, worked at FMEA as the main quality improvement tool, showing its influence on the awareness of the health team's errors, in decreasing the severity indexes through the development of effective corrective measures before an error occurs. Thus, the studies stated that FMEA is a useful tool to describe the reliability of a system, to compare alternative projects and to guide the improvement process $^{(18-19,23)}$.

Most of the surveys that carried out corrective actions, based on the possible failures that could occur, presented as improvement indicators of RPN. After the development of the actions, the studies compared this number and evidenced its reduction, representing a decrease in the highest risk failure modes identified by FMEA ${ }^{(20,23,27)}$.

Other research used FMEA as a pre-implementation phase for certain protocols in institutions, such as pain management in children or implementation of clinical practice guidelines. The tool was able to contribute in the identification of the main barriers and in the plan anticipating actions, for a successful implementation, guaranteeing its safety and effectiveness in providing a safer care to pediatric patients $s^{(19,25,30)}$.

A study carried out in a Neonatal ICU, in Iran, identified 68 modes of errors, which were subdivided into seven classes. For this purpose, the FMEA tool was used in order to monitor and calculate RPN. In order to reduce errors in the process, there was a need to take preventive measures related to supervision, planning changes, updating the activity as the greatest need and immediate action. The use of the tool made it possible to identify the possible causes of errors and to carry out an intervention with the team to reduce these errors ${ }^{(35)}$.

Of the 12 articles that used FMEA, 50\%(16-17,22,25,27,30) have a referential base anchored in DeRosier's tutorial ${ }^{(36)}$. This highlights the Healthcare Failure Mode and Effect Analysis (HFMEA), an adaptation of FMEA. Of the changes made, the main one was the addition of two stages: risk score and decision tree. This tool was developed by the Veterans Affairs National Center for Patient Safety (VANCPS) in $2001^{(36)}$. Of the twelve articles that used FMEA, only three ${ }^{(22,24,30)}$ used the HFMEA nomenclature.

In 2007, JC determined that health units should conduct an annual investigation of sentinel events using $\mathrm{RCA}^{(37)}$. Even after this determination, it is suggested that the lack of interest in using this tool is due to the fact that it performs retrospective data analysis, being susceptible to failures due to underreporting and incomplete data in medical records, due to memory failures and unclassified reliable ${ }^{(38)}$.

Analyzing the references found in Chart 1, it is observed that, of the three articles that used RCA as a tool of choice ${ }^{(24,26-27)}$, two endorsed JC. It is believed that the choice of this institution is due to the international recognition of the work developed since 1917, raising the level of quality of care through the accreditation of health institutions, making available publications, such as the book "Root Cause Analysis in Health Care: Tools and Techniques", first published in $2000^{(37)}$.

A research carried out in Queensland, Australia, sought to assess the effectiveness of the implementation of RCA after incidents involving pediatric patients in public hospitals in the country. The study evidenced RCA as a highly effective tool in detecting factors that led to error in the institutions studied, such as: late diagnosis, adverse events in the procedure and medication administration, and errors in patient identification. It was approached that, from the survey of these factors, it became possible to implement actions aimed mainly at physical changes in the structure of hospitals, the standardization of procedures and care and training and staff involvement with patient safety ${ }^{(39)}$.

Interventions are important to raise the level of quality of an institution. Of the 15 selected articles, 11 (73.3\%) performed the necessary interventions ${ }^{(16-17,19-21,23-26,28,30)}$ to mitigate risks, a fact that suggests the concern of the multidisciplinary team with patient safety.

Despite this, only two $(13.3 \%)^{(19,25)}$ introduced team education in the proposed interventions. Health education has become a relevant strategy for work transformations, becoming an environment of critical, reflective, committed and technically competent performance ${ }^{(38)}$. It is, therefore, an indispensable tool in the construction of professional competence, contributing to the organization of work, having as its main challenge the incentive to develop awareness among professionals about their context, in which each person understands their responsibility in their ongoing training process ${ }^{(40)}$.

Four $(26.6 \%)^{(20,24,27-28)}$ of the 15 articles did not mention the use of indicators, aiming at patient safety, however they describe the tool deployment and the results achieved.

Some studies have reported the limitations in the use of FMEA, such as its subjectivity, its qualitative character, the difficulties in assembling a multidisciplinary team with involvement in the processes and the time spent to achieve the objectives ${ }^{(18,22,25)}$. Despite this, the use of this tool has been recommended to

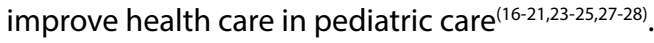

It is evident, as the main difficulty found by the study, the scarcity of articles related to the theme; therefore, despite the careful search developed by the researchers using different combinations of keywords and descriptors in the fifteen databases selected for the study, it is likely that some studies with high methodological quality have not been found.

Thus, pediatric health care units are seen as an environment to be explored in the search for quality improvement opportunities, using the tools presented here.

\section{Study limitations}

The limitations of this scoping review highlight some points to be made: the fact that most articles have presented FMEA as a tool of choice in relation to RCA, it is possible to have restricted the comparison between the tools. Furthermore, the clipping of languages can also be considered as a limitation for the present study.

Moreover, although a variety of topics have been presented using the FMEA tool, there are many other critical processes in pediatric units that have not been addressed and that need to be subjected to quality tools subject to improvement such as: assistance to preterm neonates; transfer of critical pediatric patients to other health units; cardiopulmonary resuscitation in 
pediatrics; contact isolation in pediatric wards; critical patient care in pediatric wards.

\section{Contributions to nursing, health, and public policies}

It is perceived that the application of the referred tools in patient safety can contribute to a higher quality of health care both in pediatric units and in all hospital sectors, whether locally or across the country. Such instruments can help professionals, as well as the management of health units, to develop safer practices, ensuring an efficient and organized safety culture.

\section{FINAL CONSIDERATIONS}

After analyzing literature, applying FMEA and RCA caused significant changes and improvements in the services that implemented them. Such tools showed satisfactory quality to detect opportunities for improvements in health care, employing specific methodologies for harm reduction and, thus improving patient safety.

The scientific evidence identified in this study makes it possible to indicate the use of the RCA and FMEA tools in the care provided in pediatric units. With this review, it was possible to identify the way they used FMEA and/or RCA in the approach of different problems, the interventions carried out for the improvement or for the prevention of possible errors, as well as the assessments of the improvement indicators after tool implementation, showing good post-intervention repercussions.

\section{SUPPLEMENTARY MATERIAL}

This manuscript is the result of a master's thesis linked to Graduate Program in Quality Management in Health Services of the Federal University of Rio Grande do Norte and was added to the institutional repository, at the link: https://repositorio.ufrn. br/handle/123456789/26606.

\section{REFERENCES}

1. Agência Nacional de Vigilância em Saúde - ANVISA. Assistência segura: uma reflexão teórica aplicada à prática. Série Segurança do paciente e qualidade em serviços de saúde [Internet]. Brasília: ANVISA; 2017 [cited 2019 Nov 04]. 168p. Available from: http://portal.anvisa.gov.br/ documents/33852/3507912/Caderno+1+-+Assist\%C3\%AAncia+Segura++Uma+Reflex\%C3\%A3o+Te\%C3\%B3rica+Aplicada+\%C3\%A0+Pr\% C3\%A1tica/97881798-cea0-4974-9d9b-077528ea1573

2. Agência Nacional de Vigilância Sanitária - ANVISA. Documento de referência para o Programa Nacional de Segurança do Paciente [Internet]. Fundação Oswaldo Cruz. Brasília: Ministério da Saúde; 2014 [cited 2019 Nov 04]. 42p. Available from: http://bvsms.saude.gov.br/ bvs/publicacoes/documento_referencia_programa_nacional_seguranca.pdf

3. Belela ASC, Peterline AS, Pedreira MLG. Disclosure of medication error occurrence in pediatric intensive care unit. Rev Bras Ter Intensiva. 2010;22(3):257-63. https://doi.org/10.1590/S0103-507X2010000300007

4. Menezes LCC. Análise de causa raiz e análise modal de falhas e efeitos em unidades de terapia intensiva: uma revisão sistemática [Dissertação] [Internet]. Natal: Universidade Federal do Rio Grande do Norte; 2016 [cited 2018 Jun 20]. 53 p. Available from: https:// repositorio.ufrn.br/jspui/handle/123456789/21932

5. Galdino SV, Reis EMB, Santos CB, Soares FP, Lima FS, Caldas JG, et al. Ferramentas de qualidade na gestão dos serviços de saúde: revisão integrativa da literatura. Rev Gestão Saúde [Internet]. 2016 [cited 2018 Jun 18];7(suppl-1):1023-57. Available from: https://periodicos.unb.br/ index.php/rgs/article/download/3569/3252

6. Department of Veterans Affairs Veterans Health Administration Transmittal Sheet Washington. VHA national patient safety improvement handbook [Internet]. Washington: Transmittal Sheet, 2011 [cited 2018 Jul 01]. 27p. Available from: https://www.va.gov/vhapublications/ ViewPublication.asp?pub_ID=2389

7. Silveira CC, Gomes MC. [Corrective Action: root cause analysis of defects and proposed action plan]. Rev Tecnol Projeção [Internet]. 2014 [cited 2018 Jun 18];5(1):13-28. Available from: http://revista.faculdadeprojecao.edu.br/index.php/Projecao4/article/view/379/330 Portuguese

8. Joint Commission Resources. Root Cause Analysis and Action Plan Framework Template [Internet]. Illinois (EUA); 2017 [cited 2018 Jul 01]. Available from: https://www.jointcommission.org/framework_for_conducting_a_root_cause_analysis_and_action_plan/

9. Teixeira TCA, Cassiane SHB. Root cause analysis of falls and hospital medication errors. Acta Paul Enferm. 2014;27(2):100-7. https://doi. org/0.1590/1982- 0194201400019

10. Rienzi L, Bariani F, Zorza MD, Romano S, Scarica C, Maggiulli R, et al. Failure mode and effects analysis of witnessing protocols for ensuring traceability during IVF. Reprod Biomed. 2015;31(4):516-22. https://doi.org/10.1016/j.rbmo.2015.06.018

11. Souza FT, Garcia MC, Rangel PPS, Rocha PK. Perception of nursing on the risk factors related to the pediatric patient safety. Rev Enferm UFSM. 2014;4(1):152-62. https://doi.org/10.5902/217976928781

12. Gaita MC, Fonata RT. Perceptions and knowledge about Pediatric patient safety. Esc Anna Nery. 2018;22(4):e20170223. https://doi. org/10.1590/2177-9465-EAN-2017-0223

13. Peters MDJ, Godfrey C, McInerney P, Munn Z, Tricco AC, Khalil, H. Chapter 11: Scoping Reviews (2020 version). In: Aromataris E, Munn Z (Editors). JBI Manual for Evidence Synthesis, JBI, 2020. https://doi.org/10.46658/JBIMES-20-12

14. Dantas JKS, Lima LA, Silva LCMA, Lima MSM, Dantas DV, Dantas RAN. Análise de causa Raiz, falhas e feitos na gestão de qualidade total em pediatria: scoping review. Epub ahead of print. OSF. 2021. https://doi.org/10.17605/OSF.IO/BQ678 
15. Tricco AC, Lillie E, Zarin W, O'Brien KK, Colquhoun H, Levac D, et al. PRISMA extension for scoping reviews (PRISMA-ScR): checklist and explanation. Ann Intern Med. 2018;169(7):467-73. https://doi.org/10.7326/M18-0850

16. Van Tilburg CM, Leistikow IP, Rademaker CMA, Bierings MB, Dijk ATHV. Health care failure mode and effect analysis: a useful proactive risk analysis in a pediatric oncology ward. Qual Saf Health Care. 2006;15(1):58-63. https://doi.org/10.1136/qshc.2005.014902

17. Martin LD, Verma EBGS, Latham GJ, Rampersad SE, Martin LD. Outcomes of a Failure Mode and Effects Analysis for medication errors in pediatric anesthesia. Paediatr Anaesth. 2017;27(6):571-80. https://doi.org/10.1111/pan.13136

18. Daverio M, Fino G, Luca B, Zaggia C, Pettenazzo A, Parpaiola A, et al. Failure mode and effective analysis ameliorate awareness of medical errors: a 4-year prospective observational study in critically ill children. Paediatr Anaesth. 2015;25(12):1224-7. https://doi.org/10.1111/ pan. 12772

19. Rodríguez SM, Galindo ACS, Herce JL, Hernández MAC, Peinado II, Álvarez AC, et al. Risks in the implementation and use of smart pumps in a pediatric intensive care unit: application of the failure mode and effects analysis. Int J Technol Assess Health Care. 2014;30(2):210-7. https://doi.org/10.1017/S0266462314000051

20. Lago P, Bizzarri G, Scalzotto F, Parpaiola A, Amigoni A, Putoto G, et al. Use of FMEA analysis to reduce risk of errors in prescribing and administering drugs in paediatric wards: a quality improvement report. BMJ Open. 2012;2(6):1-9. https://doi.org/10.1136/ bmjopen-2012-001249

21. Berruyer M, Atkinsona S, Lebela D, Bussie'res JF. Failure mode and effects analysis (FMEA) of insulin in a mother-child university-affiliated health center. Arch Pediatr. 2016;21(1):1-8. https://doi.org/10.1016/j.arcped.2015.09.033

22. Dehnavieh R, Ebrahimipour H, Taleghani YM, Najar AV, Hekmat SN, Esmailzdeh H. Proactive Risk Assessment of Blood Transfusion Process, in Pediatric Emergency, Using the Health Care Failure Mode and Effects Analysis (HFMEA). Glob J Health Sci. 2015;7(1):322-31. https://doi. org/10.5539/gjhs.v7n1p322

23. Apkon M, Leonard J, Probst L, DeLizi L, Vitale R. Design of a safer approach to intravenous drug infusions: failure mode effects analysis. Qual Saf Health Care. 2004;13(4):265-71. https://doi.org/10.1136/qshc.2003.007443

24. Robinson DL, Heigham M, Clark J. Using Failure Mode and Effects Analysis for safe administration of chemotherapy to hospitalized children with cancer. J Comm J Qual Patient Saf. 2006;32(3):161-6. https://doi.org/10.1016/s1553-7250(06)32021-1

25. Babiker A, Amer YS, Osman ME, Al-Eyadhy A, Fatani S, Mohamed S, et al. Failure Mode and Effect Analysis (FMEA) may enhance implementation of clinical practice guidelines: an experience from the Middle East. J Eval Clin Pract. 2018;24(1):206-11. https://doi. org/10.1111/jep.12873

26. Jayashre M, Sasidharan R, Singhi S, Nallasamy K, Baalaaji M. Root cause analysis of diabetic ketoacidosis admissions at a tertiary referral pediatric emergency department in North India. Indian J Endocrinol Metab. 2017;21(5):710-4. https://doi.org/10.4103/ijem.IJEM_178_17

27. Bonnabry P, Cingria L, Sadeghipour F, Ing H, Christ CF, Pfister RE. Use of a systematic risk analysis method to improve safety in the production of pediatric parenteral nutrition solutions. Qual Saf Health Care. 2005;14(2):93-8. https://doi.org/10.1136/qshc.2003.007914

28. Morse RB, Pollack MM. Root cause analyses performed in a children's hospital: events, action plan strength, and implementation rates. J Healthc Qual. 2012;34(1):55-61. https://doi.org/10.1111/j.1945-1474.2011.00140.x

29. Tjia I, Rampersad S, Varughese A, Heitmiller E, Tyler DC, Lee AC, et al. Wake Up Safe and root cause analysis: quality improvement in pediatric anesthesia. Anesth Analg. 2014;119(1):122-36. https://doi.org/10.1213/ANE.0000000000000266

30. Bhalla T, Dairo OO, Martin D, Wrona S, Fetzer M, Taghon T, et al. A proactive risk assessment by utilizing 'Healthcare Failure Mode and Effect Analysis' (HFMEA) for safe implementation of peripheral nerve catheters in pediatric patients. APIC. 2014;18(1):21-4. https://doi. org/10.1016/j.jpain.2012.01.282

31. Agência Nacional de Vigilância Sanitária - ANVISA. Gestão de riscos e investigação de eventos adversos relacionados à assistência à Saúde. Série Segurança do paciente e qualidade em serviços de saúde [Internet]. Brasília: ANVISA, 2017 [cited 2018 Jul 02]. 92p. Available from: https://www20.anvisa.gov.br/segurancadopaciente/index.php/publicacoes/item/ caderno-7-gestao-de-riscos-e-investigacao-de-eventos-adversos-relacionados-a-assistencia-a-saude

32. Yamamoto MS, Peterlink MAS, Bohomol E. Spontaneous reporting of medication errors in pediatric university hospital. Acta Paul Enferm. 2011;24(6):766-71. https://doi.org/10.1590/S0103-21002011000600006

33. World Health Organization (WHO). Conceptual framework for the international classification for patient safety [Internet]. Geneva; 2009 [cited $2018 \mathrm{Jul}$ 01]. Available from: https://www.who.int/patientsafety/taxonomy/icps_full_report.pdf

34. Predebon CM, Silva SC, Olaves FS, Kantorski KJC, Pedro ENR, Wegner W. Perfil das notificações de incidentes analisados pela comissão de qualidade e segurança pediátrica. In: ANAIS - I Congresso Internacional da Rebraensp [Internet]. 2016 [cited 2019 Nov 04]. Available from: https://www.lume.ufrgs.br/bitstream/handle/10183/140646/000991213. pdf?sequence=1

35. Najar AV, Ghane H, Ebrahimipour H, Nouri GA, Dadpour B. Identification of priorities for medication safety in the neonatal intensive care unit via failure mode and effect analysis. Iranian J Neonatol[Internet]. 2016 [cited 2020 Aug 12];7(2):28-34. Available from: http://ijn.mums.ac.ir/ article_7113.html

36. DeRosier J, Stalhandske E, Bagian JP, Tina NMS. Using health care failure mode and effect analysis: the VA National Center for Patient Safety's prospective risk analysis system. J Comm Qual Improv. 2002;28(5):248-67. https://doi.org/10.1016/S1070-3241(02)28025-6 
37. Joint Commission Resources. Joint Commission International. Root Cause Analysis in Health Care: Tools and Techniques. 5. ed. Oak Brook: The Joint Commission; 2015.

38. Ceccim RB. Permanent health education: decentralization and dissemination of pedagogical capacity in health. Ciênc Saúde Colet. 2005;10(4):975-86. https://doi.org/10.1590/S1413-81232005000400020

39. Hamilton MJ, MCEniery JA, Osborne JM, Coulthard MG. Implementation and strength of root cause analysis recommendations following serious adverse events involving paediatric patients in the Queensland public health system between 2012 and 2014. J Paediatr Child Health. 2019;55(9):1070-6. https://doi.org/10.1111/jpc.14344

40. Ricaldoni CAC, Sena RR. Permanent education: a tool to think and act in nursing work. Rev Latino Am Enferm. 2006;14(6):837-42. https://doi. org/10.1590/S0104-11692006000600002 